Physical Disability and Labor Market Discrimination :

Evidence from a Field

Experiment

CHARLES BELLEMARE

MARION GOUSSÉ

GUY LACROIX

STEEVE MARCHAND 


\title{
2018s-15
}

\section{Physical Disability and Labor Market Discrimination: Evidence from a Field Experiment}

\author{
Charles Bellemare, Marion Goussé, Guy Lacroix, Steeve Marchand
}

\begin{tabular}{c}
\hline Série Scientifique \\
Scientific Series
\end{tabular}

\section{Montréal \\ Avril/April 2018}

(C) 2018 Charles Bellemare, Marion Goussé, Guy Lacroix, Steeve Marchand. Tous droits réservés. All rights reserved. Reproduction partielle permise avec citation du document source, incluant la notice ${ }^{\complement}$. Short sections may be quoted without explicit permission, if full credit, including $@$ notice, is given to the source.

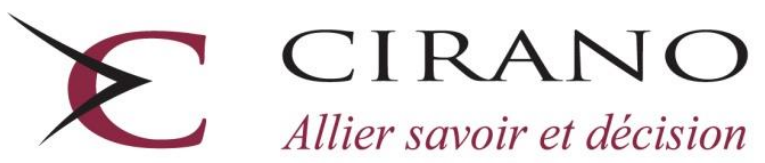

Centre interuniversitaire de recherche en analyse des organisations 


\section{CIRANO}

Le CIRANO est un organisme sans but lucratif constitué en vertu de la Loi des compagnies du Québec. Le financement de son infrastructure et de ses activités de recherche provient des cotisations de ses organisations-membres, d'une subvention d'infrastructure du gouvernement du Québec, de même que des subventions et mandats obtenus par ses équipes de recherche.

CIRANO is a private non-profit organization incorporated under the Quebec Companies Act. Its infrastructure and research activities are funded through fees paid by member organizations, an infrastructure grant from the government of Quebec, and grants and research mandates obtained by its research teams.

\section{Les partenaires du CIRANO}

\section{Partenaires corporatifs}

Autorité des marchés financiers

Banque de développement du Canada

Banque du Canada

Banque Laurentienne

Banque Nationale du Canada

Bell Canada

BMO Groupe financier

Caisse de dépôt et placement du Québec

Énergir

Hydro-Québec

Innovation, Sciences et Développement économique Canada

Intact Assurance

Investissements PSP

Ministère de l'Économie, de la Science et de l'Innovation

Ministère des Finances du Québec

Mouvement Desjardins

Power Corporation du Canada

Rio Tinto

Ville de Montréal

\section{Partenaires universitaires}

École de technologie supérieure

HEC Montréal

Institut national de la recherche scientifique

Polytechnique Montréal

Université Concordia

Université de Montréal

Université de Sherbrooke

Université du Québec

Université du Québec à Montréal

Université Laval

Université McGill

Le CIRANO collabore avec de nombreux centres et chaires de recherche universitaires dont on peut consulter la liste sur son site web.

Les cahiers de la série scientifique (CS) visent à rendre accessibles des résultats de recherche effectuée au CIRANO afin de susciter échanges et commentaires. Ces cahiers sont écrits dans le style des publications scientifiques. Les idées et les opinions émises sont sous l'unique responsabilité des auteurs et ne représentent pas nécessairement les positions du CIRANO ou de ses partenaires.

This paper presents research carried out at CIRANO and aims at encouraging discussion and comment. The observations and viewpoints expressed are the sole responsibility of the authors. They do not necessarily represent positions of CIRANO or its partners. 


\title{
Physical Disability and Labor Market Discrimination: Evidence from a Field Experiment
}

\author{
Charles Bellemare*, Marion Goussét, Guy Lacroix, Steeve Marchand ${ }^{\S}$ **
}

\begin{abstract}
Résumé/Abstract
We investigate the determinants and extent of labor market discrimination to-ward people with physical disabilities using a large scale field experiment. Appli-cations were randomly sent to 1477 private firms advertising open positions. We find that average callback rates of disabled and non-disabled applicants are respec-tively $14.4 \%$ and $7.2 \%$. We find this differential does not result from accessibility constraints related to firm infrastructures. We also find that mentioning eligibility to a government subsidy to cover the cost of workplace adaptation does not in-crease callback rates. Finally, we estimate that a lower bound of the proportion of discriminating firms is $49.7 \%$.
\end{abstract}

Mots clés/Keywords: Discrimination; Disabilities; Partial Identification

Codes JEL/JEL Codes: J71; J68

\footnotetext{
* Corresponding author: Charles.Bellemare@ecn.ulaval.ca

${ }^{\dagger}$ Marion.Gousse@ecn.ulaval.ca

¥uy.Lacroix@ecn.ulaval.ca

§Steeve.Marchand@ecn.ulaval.ca

** CRREP, Département d'économique, Université Laval. Québec, Canada
} 


\section{Introduction}

The United Nations Convention on the Rights of Persons with Disabilities (UNCRPD) entered into force in May 2008. Its purpose is to protect the well-being of persons with disabilities, promote equality and eliminate discrimination. Many countries ratified the UNCRPD, including Canada in 2010. Recent evidence suggests that persons with disabilities in Canada face similar problems to what is observed elsewhere in the world. A recent report by the Canadian Humans Right Commission shows that adults with disabilities are currently half as likely to complete a university degree, are more likely to be employed part-time, and are more likely to rely on government transfers as their main source of revenue (Canadian Humans Right Commission, 2012). Such a labor market gap has clear

fiscal and economic implications for persons with disabilities, for society at large, but also for policy makers seeking to uphold the UNCRPD's goals.

In the Province of Québec, the National Strategy for Labour Market Integration and Maintenance of Handicapped Persons was implemented in 2008 to achieve employment equality and increase labor market participation of people with handicaps. The Strategy aimed at halving the gap within the next decade by providing individuals and firms various tools to enhance their employment prospects. These include wage subsidies and financial assistance to firms to reduce or eliminate costs of adapting the work environment to specific needs. Yet, as of 2012, the employment rates of disabled males and females were still 20 and 24 percentages points lower than those of able bodied individuals, respectively (Gouvernement du Québec, 2013). The ineffectiveness of programs aimed at improving employment outcomes has also been documented in other developed countries (see Acemoglu and Angrist (2001), Bell and Heitmuller (2009)).

Many factors may explain the poor labor market outcomes of persons with disabilities, and the relative ineffectiveness of incentives and programs. Standard supply-side economics focuses on preferences and skills of individuals as determinants of their earnings potential, reservation wages, and labor supply (see Blundell and MaCurdy, 1999). On the demand side, firms are assumed to maximize profits, leading them to hire the most productive workers. However, profit maximization raises some challenges for per- 
sons with disabilities if they are unduly perceived as being less productive or more costly to integrate in the workplace. Inaccurate perceptions on the demand side may thus foster discriminatory practices. Indirect evidence suggests that discrimination facing persons with disabilities may be sizable. A recent report stresses that $49 \%$ of all discriminatory complaints filed between 2009 and 2013 with the Human Rights Commission and tribunals across Canada were related to disability issues (Canadian Humans Right Commission, 2015). Furthermore, $84.3 \%$ of the latter were employment related, suggesting that discrimination may be an important barrier preventing disabled individuals from fully benefiting from the labor market.

In this paper we provide direct evidence on the determinants of labor market discrimination facing people with acute physical disabilities (wheelchair users) using data from a large scale field experiment conducted in Québec (Canada). Applications (cover letter and CV) were randomly sent to 1477 private firms operating in two urban regions (Montréal and Québec City) advertising open positions. Our experimental design targeted positions for which paraplegia is considered to have no bearing on productivity. These include positions for receptionists, secretaries, computer programmers, and accounting clerks. We used the same profile for females applying for secretary and receptionist positions. We further randomized applications for computer programmer and accounting clerk positions on the basis of gender and education level. Overall, applications were sent for positions covering a large range of educational attainments, from post-secondary education to university degrees. Cover letters randomly disclosed a physical disability. The extensive and intensive margins of disabilities were also varied by indicating the year the applicant became disabled. Applications for all positions were additionally randomized to vary work history, and whether the applicant was beneficiary of a government subsidy to adapt his work environment at no extra cost to the firm. Randomizing the mention of this subsidy in the cover letter allows to evaluate the effectiveness of one of the main programs of Québec's National Strategy - known as the Job Integration Contract. This program offers firms wage subsidies that can cover up to $85 \%$ of wages (depending on the severity of the disability), $50 \%$ of the costs to provide physical access to workplaces (wheelchair ramps, 
automatic doors, etc.), and $100 \%$ of the costs to adapt the workspace of the disabled employee (tables and disability related equipment). The Job Integration Contract includes two components - a wage subsidy and a reduction of infrastructure spending required to provide access to an adapted office for persons with disabilities. Firms analyzing applications revealing a disability (with or without a Job Integration Contract) may simply refuse to interview candidates because their workplace is not accessible. Controlling for workplace access is important in the present paper since the Job Integration Contract only partially covers expenses to provide access. We addressed this issue by anonymously visiting a subsample of firms who received applications in our experiment in order to document workplace access including presence of an access ramp and/or elevator.

We find that average callback rates for applications with and without an indication of disabilities are $7.2 \%$ and $14.4 \%$ respectively, which implies that disability reduces callback rates by $50 \%$. We further find that discrimination is significant among three of the four positions targeted in the experiment. Interestingly, we find little significant evidence of discrimination for computer programmers, the most highly skilled position covered by our experimental design. We also find that signalling availability of a subsidy to reduce or eliminate the costs of adapting workplace environments does not significantly reduce measured discrimination. The most straightforward interpretation of our results is that firms simply dislike hiring persons with disabilities. However, this interpretation overlooks the possibility that firms in our experiment may be able to accommodate persons with disabilities only at prohibitive additional costs not covered by the Job Integration Contract. Our results show that differences in callback rates largely persist regardless of existing infrastructure and workplace access.

These results contribute to a small literature measuring discrimination facing persons with disabilities through fictitious randomized applications. Ravaud et al. (1992) sent non-solicited applications to a sample of 2228 firms in France. They varied the mention of a physical deficiency (paraplegia with a wheelchair) and the qualification level of the applicant. Their results support the hypothesis that persons with disability are discriminated against. The closest study to our paper in terms of methodology is Ameri et al. 
(2017) who measure disability related discrimination by sending 6016 applications in the United States. They focus on highly educated males applying for skilled accounting positions. They consider disabilities related to either Asperger's syndrome or spinal cord injuries. They find that the average callback rates for applications with and without mentions of disabilities are $4.87 \%$ and $6.58 \%$ respectively, which represents a $26 \%$ lower callback rate for the former. Our paper extends these results by analyzing the effects of a richer set of firm specific characteristics and required skill levels, the latter being a potentially significant determinant of discrimination. A related literature has documented the relative ineffectiveness of wage subsidies in increasing call-back rates for persons with disabilities (Deuchert and Kauer (2017), Baert (2016)). One limitation of these studies is that they do not control for the possible confounding effects of workplace accessibility and existing infrastructure (lack of access ramps and/or elevators). They also do not consider a program aimed at jointly offering wage subsidies and compensation to offset infrastructures expenses aimed at facilitating integration of persons with disabilities in the workplace.

The final part of the paper shows how differences in callback rates between applications with and without the mention of a disability can be used to bound the proportion of discriminating firms in our sample. The bounding approach holds under the assumption that applications not revealing a disability have the same callback rates from discriminating and non-discriminating firms. Gathering knowledge about the proportion of discriminating firms in the labor market is important in its own right, but also because it provides information on a central parameter of structural models of labor market discrimination. In such models, discrimination is usually identified through functional form assumptions about the shape of the observed income distribution (see e.g. Flabbi (2010), Bowlus and Eckstein (2002)). Bounding the proportion of discriminating firms using data from a field experiment enriches the empirical content of these models while providing added value to field experiments having measured various forms of discrimination using a similar methodology (Lahey (2008), Oreopoulos (2011)). We find that differences in callback rates in our experiment (aggregated across jobs) are consistent with a minimum 
of $49.7 \%$ of firms discriminating against persons with disabilities. Job specific bounds show some heterogeneity. While the lower bound remain high for positions of secretary (minimum of $72.9 \%$ ), receptionist (minimum of 55,9\%), and accounting clerk (minimum of $72,8 \%$ ), the lower bound falls to a minimum of $6.3 \%$ for computer programmers. The later reflects the fact that measured discrimination is significantly smaller for computer programmers, a finding shown to be consistent with a significantly lower proportion of firms discriminating.

The paper is organized as follows. Section 2 presents the experimental design and procedures. Section 3 presents the data and empirical results. Section 4 concludes.

\section{Experimental Design}

Paraplegia is a lesion of the spinal cord that results in paralysis and loss of sensations in some parts of the lower body, making the person unable to walk. The most common mobility device used by paraplegics is a wheelchair. If the work environment is adapted for wheelchairs to circulate properly, paraplegia in itself should not affect productivity for a wide range of jobs, e.g. administrative or computer jobs involving office tasks. Our experimental design targets jobs for which paraplegia should have minimal impact on productivity such as secretary, receptionist, computer programmer, and accounting clerk. We targeted jobs posted in the metropolitan areas of Montréal and Québec City in Canada. Applications were sent to selected job postings for our target positions within a 100 kilometer radius of both cities.

Our fictitious applications were developed in collaboration with a local community organization (La Croisé, http://www.lacroise.ca/) whose mission is to assist persons with disabilities through their job search. This organization provided us with a set of applications drawn from their archives of persons living with physical disabilities. We used this set of applications to develop representative templates which could be generated using a custom computer program. Our templates were subsequently validated by this organization before being fielded. 
Each fictitious application contained two pages: a cover letter and a resume. The computer program allowed to determine specific inputs in each application (target position, spoken and written languages, etc.), and allowed to vary other elements on the application randomly including mention of disability, availability of subsidies to firms hiring persons with disabilities, gender (when relevant), and work history (years of experience, unemployment spells). The computer program ensured that the combination of characteristics in a given application was consistent. For example, work experience could not begin before education and training ended. We next describe the content of the cover letters and resumes.

\subsection{Cover letters}

The Appendix provides an example (translated into English) of a typical cover letter. We used two names for the fictitious job applicants: "Jessica Gagnon" and "Jonathan Gagnon". Gagnon is among the most common last names in the province of Québec, while Jessica and Jonathan are respectively among the most common female and male given names. A name specific phone number was used and the voice mail messages of Jessica and Jonathan were respectively recorded by a female and male responder. The voice mail messages simply stated: "Hello, this is Jessica (Jonathan) Gagnon. Please leave a message and I will call you back shortly". Both responders who recorded voice messages for the experiment were in their early thirties, the average age group in our sample of applications (see below). A common e-mail address was used for all applications (i.e. jgagnon35@hotmail.com).

All cover letters first contained a generic presentation that varied with respect to the position sought. This generic presentation highlighted past voluntary work as well as written and spoken fluency in both French and English.

The key elements for this experiment were varied through the cover letter. A subset of applications mentioned a physical disability, and a subset of those also mentioned the availability of government financial assistance to adapt the workplace. Disability was disclosed in a subset of applications by including the following sentence : "I would like to 
mention that, following an accident in year X, I am using a wheelchair. Please note that this does not impair the quality of my work in any way". Year X was randomly selected under specific logical constraints. ${ }^{1}$ Varying $X$ allows to test whether discrimination varies with the duration of the disability. In particular, persons who have spent many years with a disability may be perceived as more able to face possible workplace challenges. Approximately half the applications disclosing a physical disability were randomly chosen to reveal an additional piece of information relating to eligibility of financial assistance to firms. As discussed in the introduction, the government of Québec provides financial assistance through its Job Integration Contract. This program offers firms wage subsidies that can cover at most $85 \%$ of wages (depending on the severity of the disability), $50 \%$ of the costs to provide physical access to workplaces (wheelchair ramps, automatic doors, etc.), and $100 \%$ of costs to adapt the workspace of the disabled employee (tables and disability related equipment). The subsidy is available to positions in a standard working environment and ensures proper coaching for the employee. This information was revealed by adding the following sentence : "Please note that you are entitled to a financial support that covers all expenses necessary to adapt your work environment to my situation".

\subsection{Resumes}

For each target position, we generated resumes with relevant and credible academic degrees and work experience. The Appendix provides an example of a typical resume (translated in English). In addition to the name and contact information (also appearing on all cover letters), resumes contained the following information.

Education always appeared at the top of the resume. For all positions, resumes listed both a high school and a post-secondary diploma. Computer programmer applications additionally mentioned either a post-secondary (community college) degree or a university degree, depending on the requirements of the position. They also indicated an internship

\footnotetext{
${ }^{1}$ Year $X$ is constrained to be greater than the year of birth that could be inferred by the employer from the starting year of high school that appears in the resume (see below). It is also constrained to be smaller than the year the resume is sent.
} 
in a fictitious firm during the last year of education, as this is standard practice in this field. In all cases, diplomas mentioned existing schools names within the target city. The year the last diploma was awarded was randomly generated and all the other years mentioned in this section are determined accordingly as a function of the diplomas' standard completion times. $^{2}$ Employers can use these two pieces of information to infer the age of the candidate (It is very uncommon to state one's age in a resume in Québec.) For example, consider a resume sent in 2016. If the resume indicates starting high school in 1999, and considering high school usually starts at age 12 , the employer may reasonably infer that the candidate is about 29 years old $(2016-1999+12)$.

Professional experience followed immediately after the education. All resumes indicated one past job experience of relevance to the target position. This experience was in all cases related to past employment with a fictitious firm in the target city. Within a target position, only the years at which the candidate started and finished working in the fictitious firm vary randomly across resumes. Around half the resumes indicated that the candidate was still working the year the resume was sent (i.e. 2016 or 2017). The other resumes indicated that the candidate had not worked during the year the resume was sent as well as the previous year. This allows us to test whether callback rates and discrimination vary if the candidate is not currently employed. Furthermore, we also vary randomly the year the candidate stopped working (for those who stopped). We can therefore test whether the duration of the inactivity period affects callback rates and discrimination. We also vary randomly the year at which the candidate started working at the fictitious firm, thus breaking the collinearity between experience (measured by the number of years worked for the firm) and age (as potentially inferred by the employer from the method explained above) thus allowing us to identify the two effects separately.

Computer skills were indicated near the bottom of each resume. All resumes indicated "Office Suite". Resumes for accounting clerk positions additionally indicated a

\footnotetext{
${ }^{2}$ For example, take a resume for an accounting clerk with a diploma awarded in 2007 . The standard duration of such training includes a five-year high-school diploma and a three-year college diploma. In this example, the resume would state high-school attendance from 1999 to 2004 and community college training from 2004 to 2007 .
} 
standard bookkeeping software, while applications for programmers listed a series of standard programming languages and softwares. Resumes concluded by indicating volunteer work experience at the Canada Revenue Agency, French as mother tongue, and advanced written and spoken fluency in English. Hobbies included listening to music and reading.

\subsection{Measuring callback rates}

1477 applications were sent between May 2016 and April 2017 to positions advertised on on-line job search engines (Indeed.ca, emploiquebec.gouv.qc.ca). We excluded job offers which has been posted on-line for more than two weeks to focus on employers with potentially unfilled positions. A single resume was sent to each position. Employers could leave a message on the candidate's voice mail or send an e-mail to either invite the fictitious candidate to a formal interview or to ask for additional information. Our main analysis presented bellow considers the application successful if it received a request for a formal job interview, which can be seen as a conservative definition of callback. We also conduct a robustness analysis that considers successful any attempt from the employer to contact the candidate (e.g. requesting additional information or to discuss before conducting a formal interview), unless the message is negative. ${ }^{3}$ In order to limit the inconvenience, employers having contacted the fictitious candidates where informed by email within 48 hours that the candidate in question had found another job and was therefore not interested in pursuing matters any further.

\subsection{Firm characteristics and workplace accessibility}

All applications were linked to addresses of firms to which they were sent. We used the provincial public registry of firms operating in the province of Québec to retrieve indicators of firm size, proxied by the number of registered employees. ${ }^{4}$ This information was available for 1436 of the 1477 firms in our sample.

\footnotetext{
${ }^{3}$ All tables of results presented in the paper using this extended measure of callback rates are available in our online appendix.

${ }^{4}$ Registry data can be found at http://www.registreentreprises.gouv.qc.ca/en/.
} 
An important issue is to separate genuine discrimination (statistical or taste based) from the confounding effects of the lack of proper facilities for employees in wheelchairs which may serve as an explanation for low callback rates of applications indicating a physical disability. We investigated this issue by visiting 611 of the 1477 firms our applications were sent to (all firms in Quebec City and 232 firms in Montréal), documenting whether offices where accessible to wheelchair users. To be considered accessible, offices needed to be housed in buildings with an access ramp. Moreover, firms whose offices were situated above the ground floor level required an elevator to be considered accessible.

\section{Data and results}

\subsection{Application and firm characteristics}

Table 1 presents the characteristics of the applications that were sent as well as those of firms in our sample. Note that over $62 \%$ of applications disclosed a physical disability. ${ }^{5}$ Among applications disclosing a disability (923 applications), 48\% highlighted that firms were eligible to a government subsidy that would cover the costs of adapting the workplace. Moreover, the year of the accident disclosed through the cover letters indicating a disability varied from 1982 to 2015, with an average of 2004.

Overall, $28 \%$ of all applications were sent to firms operating in the metropolitan area of Québec City, and 72\% were sent in the metropolitan area of Montréal. In addition, over $47 \%$ of all applications stated that the fictitious applicant was not working at the time the application was sent. The number of years of unemployment since the last job varied from 0 to 7 , with an average of 1.72 . The average implicit age of applicants is 31.86 . This age variable is the age the candidate would have had she completed the education profile listed in her resume without any interruption. It corresponds to a measure, albeit imperfect, an employer may have of the age of the candidate given the information available in the

\footnotetext{
${ }^{5}$ We chose to generate more than $50 \%$ of the applications with disability status in order to have enough observations to allow interactions between disability and the mention of the subsidy or the number of years since the accident.
} 
resume.

Years of experience vary between 1 and 21, with an average of 8.24 years. Only $23 \%$ of all fictitious applicants are male. The later reflects our design choice of sending female applications only in response to secretary and receptionist target positions. Applications were relatively well distributed across the four target positions, with slightly more applications sent to receptionist positions $(31 \%)$ than to other three positions. The bottom panel of Table 1 presents the characteristics of the firms in our sample. Hence $71 \%$ of the 611 firms that were visited were considered accessible to wheelchair employees. Only $6 \%$ of firms mentioned in their job postings that they subscribed to a policy of promoting equal access opportunities to everyone. This mention is purely voluntary - there are no legal requirements in Québec requiring firms to mention they offer equal access opportunities, although it is illegal to discriminate. Finally, firm size proxied using publicly available registry information is relatively diverse. Of the 1436 firms (out of 1477) for which this information was available, we find $41 \%$ of firms have 10 employees or less, while $30 \%$ of firms have more than 50 employees.

\subsection{Callback rates}

Column (a) of Table 2 presents baseline callback rates for an interview by target position for applications not mentioning a physical disability. We find that callback rates range between $11.6 \%$ and $17.4 \%$ across the target positions, with a sample average callback rate of 14.4\%. These baseline rates are among the highest among those reported in related papers using fictitious applications to measure racial discrimination (see for example Bertrand and Mullainathan, 2004 and Oreopoulos, 2011) and discrimination towards persons with disabilities (Ravaud et al., 1992; Ameri et al., 2017), notwithstanding our conservative definition of callback. ${ }^{6}$ Several factors may explain why our baseline callback rates are

\footnotetext{
${ }^{6}$ If we extend our definition of callback to include any attempt from the employer to contact the candidate (unless the message is negative) on top of those seeking a formal interview, we obtain callback rates largely higher than all papers cited above. The exact definition of callback used in the literature is not usually made explicit.
} 
large. First, unemployment rates in Québec City and Montréal were at historically low levels $(4.1 \%$ and $6.1 \%$, respectively) during the period when the applications were sent. Second, applications were only sent to job openings that had been advertised for at most two weeks, thus focusing on vacant job positions. In contrast, Ravaud et al. (1992) sent unsolicited applications, while other studies cited above do not discuss similar restrictions in their experimental design.

Column (b) presents the difference in callback rates relative to baseline for applications disclosing a physical disability. We find that the average callback rate difference is 7.2 percentage points lower relative to baseline, a statistically significant difference. Reductions in callback rates are lowest for programmers (only 0.8 percentage points relative to baseline) and highest for secretaries (10.9 percentage points relative to baseline). The differences are statistically significant at the $1 \%$ level (two-sided tests) for all positions save for computer programmers.

Column (c) reports ratios of callback rates of baseline relative to disclosing a disability. We find on average that callback rates under baseline are almost two times higher when a physical disability is not disclosed. This ratio varies across target positions - from little more than one for computer programmers to 3.69 for secretaries. Interestingly, positions of computer programmers are the highest skilled positions in our experiment. Either discriminatory practices are traditionally limited in the field of computer programming, or education and high skill levels attenuate discrimination in the labor market.

Overall, our data suggest that wheelchair users are much more penalized in their chances of landing a job interview than what is found in the literature regarding race and ethnicity (e.g. Bertrand and Mullainathan, 2004; Oreopoulos, 2011), age (e.g. Lahey, 2008, obesity and attractiveness (e.g. Rooth, 2009; Ruffle and Shtudiner, 2014) or sexual orientation (e.g. Patacchini et al., 2015). Our data also suggest that disabled individuals may face more severe discrimination than what has been previously reported (i.e. Ravaud et al., 1992; Ameri et al., 2017; Baert, 2016). ${ }^{7}$

\footnotetext{
${ }^{7}$ One exception is Ravaud et al. (1992) who find yet higher odds ratios than ours for some firm sizes, but their differential callback rates are lower than ours.
} 
We test whether these discrimination effects may be reduced by programs or firm characteristics aimed at improving prospects for individuals with disabilities. Column (a) of Table 3 shows the callback rates for applications without the potentially beneficial individual characteristics, while column (b) presents the effect of the characteristic on the callback rates. Predictively, accessibility for wheelchair and firms promoting equal access opportunities have no significant effect on callback rate for applications not mentioning a disability. For applications mentioning a disability, we do find positive significant effects for both characteristics. Accessibility for wheelchairs increases the callback rate by 5.7 percentage points, and promoting equal access opportunities increases it by 8.7 percentage points. These effects are respectively significant at a five and one percent (one-sided) significance level. We however find no significant impact of mentioning the availability of a subsidy that would cover the costs of adapting the workplace.

\subsection{Linear Probability Models}

Table 4 presents the parameter estimates of a linear probability model which regresses callback status on resume and firm characteristics. ${ }^{8}$ Estimates are based on a subsample of 1436 firms for which information about firm size were available through the provincial registry. Table 4 first reports separate regressions for each of the four target positions (columns (a) to $(d)$ ). The four regressions have a common set of explanatory variables, including a dummy variable indicating whether a disability was revealed through the cover letter, and interactions of this variable with whether a subsidy was mentioned in the cover letter and the number of years since the accident causing the disability. Other covariates (not interacted with disability) include gender, age, labor market experience (in years), whether the application was sent in the metropolitan area of Québec City, whether the applicant currently works, the number of years of unemployment since the last job, and dummy variables to proxy firm size using the number of employees.

\footnotetext{
${ }^{8}$ The parameter estimates are very similar in magnitude and significance to the average marginal effects obtained from a probit model (available upon request). The linear probability model has the additional advantage of simplifying the interpretation of interaction effects.
} 
We find that disability significantly decreases callback rates on average for all positions but programmers. When significant, the estimated decreases in callback rates are sizeable, ranging from 9.6 percentage points to 11.7 percentage points. Interestingly, programmers are the most highly educated positions covered in our design. While the lack of discrimination may be position specific, we conjecture that the additional education may crowd out or attenuate potential discrimination. Mention of a subsidy and the number of years since the applicant became disabled have no significant impact on discrimination in all four positions.

Callback rates tend to be significantly higher in Québec City relative to Montréal for secretary and receptionist positions. The latter reflects the state of the labor market in both cities, with lower unemployment rate in Québec City relative to Montréal (see discussion in previous subsection). For secretaries, we further find a negative and significant effect of the number of years since last employment. Firm size (proxied by number of employees) has a limited impact on callback rates with one exception - firms with 11 to 25 employees have 12.4 percentage points higher callback rates than firms with 10 or less employees (reference category) for secretaries. Finally, we find no impact of a claim that a firm offers "Equal Access Employment" on callback rates. Column (e) presents estimates from a model pooling data from all four positions together, adding binary variables to control for differences across positions (secretary positions serve as reference group). Results from this specification are largely in line with the previous analysis.

The discrimination measured in the previous analysis could result from employers concerned about their firm's accessibility for wheelchairs. Column (f) presents the results from an estimation pooling all positions, made on the subsample of firms for which we observe accessibility and adding as explanatory variables the accessibility for wheelchairs (a binary variable), as well as an interaction of this variable with disability status. The estimated effect of disability remains negative and high (-10.5 percentage points) and significant, although it is less precise because of the lower number of observations. The effect of accessibility is not significant. Thus, our results provide no evidence that accessibility of the workplace to wheelchairs nullifies discrimination. 
The preceding analysis allowed the discrimination to vary across positions, with availability of a subsidy, with years since the applicant became disabled, and with accessibility of the work environment to wheelchairs. A richer set of interactions with disability status could reveal further insights on the heterogeneity of discrimination across our population. The last two columns present an extended model that uses the pooled data from all positions and interacts each variable with disability status. Column (g) presents this estimation's leading effects (variables not interacted), while column (h) presents the effects of variables interacted with disability status. The leading effect of disability is -10.9 percentage points, capturing discrimination relating to positions of secretaries (reference category). We find no significant positive effect of any variable interacted with disability. This analysis confirms previous findings and further reasserts that few factors apart from those distinguishing programmer positions can attenuate discrimination facing persons living with physical disabilities.

All results presented above defined callback as a request from the employer to proceed with a formal job interview, excluding other requests for information. Potentially, non-discriminating employers worried about the feasibility of hiring a disabled candidate could seek more information before proceeding to an interview. In this case our results above could mistake this concern for discrimination. Therefore, as a robustness analysis, we estimate our linear probability model modifying the dependant variable (callback status) to include any request from the employer to contact the candidate, unless the message is negative. Table 5 presents the results. The estimates are largely in line with the previous analysis. Since the callback rates that include information requests are necessarily larger, the estimates of the effect of disability on callback in percentage points are larger also. Excluding programmers, the negative effects of disability status are significant at a one-percent significance level for all positions, ranging from $19.3 \%$ (secretaries) to $24.9 \%$ (accounting clerks). Furthermore, the accessibility of the firm for wheelchairs does not reduce discrimination measured with this new definition of callback (see column (f)), suggesting that concerns for accessibility play no more role in employers requesting information than it does for formal interviews. 


\subsection{Bounding the proportion of discriminating firms}

In this section we show that differences in callback rates can be used to bound the proportion of discriminating firms in our sample. Our approach assumes two types of firms populate the labor market. Let a proportion $\pi$ of firms discriminate against persons with disabilities, and $d$ denote a binary indicator taking a value of 1 when a firm discriminates, 0 otherwise. The callback rate of an application without mention of a disability and with a vector of characteristics $\mathbf{x}$ is given by

$$
\operatorname{Pr}\left(\text { call }^{\text {without }} \mid \mathbf{x}\right)=\operatorname{Pr}\left(\text { call }^{\text {without }} \mid \mathbf{x}, d=1\right) \pi+\operatorname{Pr}\left(\text { call }^{\text {without }} \mid \mathbf{x}, d=0\right)(1-\pi)
$$

where $\mathbf{x}$ contains information included in the application such as gender and work experience, but not disability status. Our main assumption is the following

$$
\operatorname{Pr}\left(\text { call }^{\text {without }} \mid \mathbf{x}, d=1\right)=\operatorname{Pr}\left(\text { call }^{\text {without }} \mid \mathbf{x}, d=0\right)
$$

The later implies that both types of firms evaluate in the same way applications not mentioning a disability, yielding the same callback rates. It is possible that (2) only holds for some specific subset of application characteristics $\mathbf{x}$. This would occur if for example firms that discriminate against persons with disabilities also discriminate against female applications. In these cases, a valid bound on $\pi$ can be derived using only male applications. Such difficulties can in principle be detected in the experimental data. For example, we do not find that callback rates vary significantly with gender (see Table 4), suggesting no need to condition on gender in our analysis. Assumption 2 further implies

that $\operatorname{Pr}\left(\right.$ call $\left.l^{\text {without }} \mid \mathbf{x}, d=0\right)=\operatorname{Pr}\left(\right.$ call $\left.^{\text {without }} \mid \mathbf{x}\right)$ as both types of firm behave similarly absent a mention of a disability.

Both types of firms do however treat applications mentioning a disability differently. From (2) and the law of total probability it follows that

$$
\begin{aligned}
\operatorname{Pr}\left(\text { call }^{\text {with }} \mid \mathbf{x}\right) & =\operatorname{Pr}\left(\text { call }^{\text {with }} \mid \mathbf{x}, d=1\right) \pi+\operatorname{Pr}\left(\text { call }^{\text {with }} \mid \mathbf{x}, d=0\right)(1-\pi) \\
& =\operatorname{Pr}\left(\text { call }^{\text {with }} \mid \mathbf{x}, d=1\right) \pi+\operatorname{Pr}\left(\text { call }^{\text {without }} \mid \mathbf{x}\right)(1-\pi)
\end{aligned}
$$

Solving for $\pi$ gives 


$$
\pi=\frac{\operatorname{Pr}\left(\text { call }^{\text {with }} \mid \mathbf{x}\right)-\operatorname{Pr}\left(\text { call }^{\text {without }} \mid \mathbf{x}\right)}{\operatorname{Pr}\left(\text { call }^{\text {with }} \mid \mathbf{x}, d=1\right)-\operatorname{Pr}\left(\text { call }^{\text {without }} \mid \mathbf{x}\right)}
$$

The experimental data identify callback rates $\operatorname{Pr}\left(\right.$ call $\left.^{\text {with }} \mid \mathbf{x}\right)$ and $\operatorname{Pr}\left(\right.$ call $\left.^{\text {without }} \mid \mathbf{x}\right)$, but not $\operatorname{Pr}\left(\right.$ call $\left.^{\text {with }} \mid \mathbf{x}, d=1\right)$. The later is bounded from below at 0 , and from above at $\operatorname{Pr}\left(\right.$ call $\left.^{\text {with }} \mid \mathbf{x}\right)$ in order to restrict $\pi$ to be no greater than 1 . It follows that

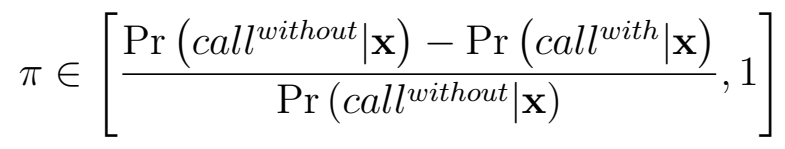

The lower bound on $\pi$ is thus a simple function of the callback rates of applications mentioning or not a disability, conditional on $\mathbf{x}$. Column (a) of Table 6 presents estimated lower bounds and their corresponding (one-sided) asymptotic confidence intervals for all positions and separately for each of the fours positions in the experiment. These estimates are obtained by replacing callback rates in (4) with estimates taken from Table 2 (we find similar values of bounds when using the definition of callback that includes any request from the employer to contact the candidate). We find that the estimated lower bound for $\pi$ using the aggregate callback rates is $49.7 \%$, suggesting that almost half of the firms in our experiment discriminate against persons with disabilities. Estimated lower bounds vary across positions, the lowest being $6.3 \%$ for programmers. The highest is for secretaries and accounting clerks (both 73\%). Column (b) presents the lower 95\% one-sided confidence interval (CI) on the estimated lower bound - an even more conservative bound of the minimum proportion of firm that discriminate. ${ }^{9}$ Confidence intervals for the lower bound is negative for programmers because the bound is not statistically significant. This reflects the relatively weak effect of discrimination measured for this profession, making it impossible to conclude there is a significant share of firms discriminating against computer programmers. However, the lower bounds of the confidence intervals are relatively high for other professions (between $36.7 \%$ and 54.3\%), providing clear evidence that a substantial share of firms discriminate against individuals with physical disabilities for these professions.

\footnotetext{
${ }^{9}$ The standard errors are calculated using the delta method.
} 


\section{Conclusion}

This paper presented direct evidence of discrimination facing persons with physical disabilities. Our design allowed to control for the confounding effects of workplace access for wheelchair users, and highlighted the relative ineffectiveness of programs aimed at lowering or eliminating hiring costs of firms. Together, these results point to a fundamental problem relating to the perception firms have of physical disabilities, even when the latter interfere in a very limited way with job requirements. Our analysis focused on persons with specific mobility restrictions. Yet, local organizations who helped design the current experiment and who support persons with disabilities in their job search efforts firmly believe that wheelchair users face the fewest hurdles integrating the labor market. We conjecture that discrimination against persons with other disabilities (e.g. mental, visual) is thus no less prominent.

We further showed how the experimental data can be used to bound the proportion of discriminating firms. These bounds can be used to assess the plausibility of corresponding estimates obtained from equilibrium labor market models taking into account discrimination but whose identification relies of functional form assumptions (e.g. Bowlus and Eckstein (2002), Flabbi (2010)). Future work should incorporate these bounds in the estimation of these models. Doing so would ease identification of these models and provide more robust policy recommendations which can be useful to foster employment of persons living with disabilities. 


\begin{tabular}{lccccc}
\hline \multicolumn{5}{c}{ Application characteristics } & \\
& Mean & SD & Min & Max & N \\
\hline Disability & 0.62 & 0.48 & 0 & 1 & 1477 \\
Subsidy & 0.48 & 0.50 & 0 & 1 & 923 \\
Year of accident & 2004 & 9.07 & 1982 & 2015 & 923 \\
Quebec City & 0.28 & 0.45 & 0 & 1 & 1477 \\
Not currently working & 0.47 & 0.50 & 0 & 1 & 1477 \\
Nb of years since last job & 1.72 & 2.11 & 0 & 7 & 1477 \\
Age & 31.86 & 5.80 & 22 & 44 & 1477 \\
Experience & 8.24 & 5.62 & 1 & 21 & 1477 \\
Male & 0.23 & 0.42 & 0 & 1 & 1477 \\
Secretary & 0.22 & 0.42 & 0 & 1 & 1477 \\
Accounting clerk & 0.22 & 0.41 & 0 & 1 & 1477 \\
Programmer & 0.25 & 0.43 & 0 & 1 & 1477 \\
Receptionist & 0.31 & 0.46 & 0 & 1 & 1477 \\
\hline \hline
\end{tabular}

Firm characteristics

\begin{tabular}{lccccc} 
& Mean & SD & Min & Max & N \\
\hline Accessible for wheelchairs & 0.71 & 0.46 & 0 & 1 & 611 \\
Equal access to employment & 0.06 & 0.25 & 0 & 1 & 1477 \\
0 to 10 employees & 0.41 & 0.49 & 0 & 1 & 1436 \\
11 to 25 employees & 0.16 & 0.36 & 0 & 1 & 1436 \\
21 to 50 employees & 0.14 & 0.34 & 0 & 1 & 1436 \\
More than 50 employees & 0.30 & 0.46 & 0 & 1 & 1436 \\
\hline \hline
\end{tabular}

Table 1: Summary statistics 


\begin{tabular}{lcccc}
\hline \hline & $\begin{array}{c}\text { Reference } \\
\text { (a) }\end{array}$ & $\begin{array}{c}\text { Diff. if disabled } \\
(\mathrm{b})\end{array}$ & $\begin{array}{c}\text { Ratio ref./disab. } \\
\text { (c) }\end{array}$ & $\begin{array}{c}\text { Observations } \\
\text { (d) }\end{array}$ \\
\hline Secretary & 0.149 & $\begin{array}{c}-0.109^{* * *} \\
(0.032)\end{array}$ & 3.691 & 327 \\
Receptionist & 0.174 & $\begin{array}{c}-0.097^{* * *} \\
(0.031)\end{array}$ & 2.268 & 461 \\
Accounting clerk & 0.116 & $\begin{array}{c}-0.085^{* * *} \\
(0.028)\end{array}$ & 3.682 & 319 \\
Programmer & 0.127 & $\begin{array}{c}-0.008 \\
(0.037)\end{array}$ & 1.067 & 370 \\
Montreal & 0.123 & $\begin{array}{c}-0.070^{* * *} \\
(0.017)\end{array}$ & 2.331 & 1059 \\
Quebec City & 0.190 & $\begin{array}{c}-0.060^{*} \\
(0.036)\end{array}$ & 1.464 & 418 \\
\hline Total & 0.144 & $\begin{array}{c}-0.072^{* * *} \\
(0.016)\end{array}$ & 1.989 \\
\hline \hline
\end{tabular}

Standard errors in parentheses

*** $\mathrm{p}<0.01,{ }^{*} \mathrm{p}<0.05,{ }^{*} \mathrm{p}<0.1$; where $\mathrm{p}$-values are for a two-sided test of proportion testing the null hypothesis that the callback rates for applications with and without a mention of disability are equal.

Table 2: Callback rates

\begin{tabular}{|c|c|c|c|c|}
\hline & $\begin{array}{l}\text { No } \\
\text { (a) }\end{array}$ & $\begin{array}{l}\text { Diff. if Yes } \\
\text { (b) }\end{array}$ & $\begin{array}{c}\text { Ratio No/Yes } \\
\text { (c) }\end{array}$ & $\begin{array}{l}\text { Observations } \\
\text { (d) }\end{array}$ \\
\hline & \multicolumn{4}{|c|}{ Disability $=0$} \\
\hline Accessible for wheelchairs & 0.177 & $\begin{array}{c}0.011 \\
(0.058)\end{array}$ & 0.942 & 216 \\
\hline \multirow[t]{2}{*}{ Equal access to employment } & 0.147 & $\begin{array}{c}-0.027 \\
(0.052)\end{array}$ & 1.224 & 554 \\
\hline & \multicolumn{4}{|c|}{ Disability $=1$} \\
\hline Accessible for wheelchairs & 0.051 & $\begin{array}{l}0.057^{* *} \\
(0.032)\end{array}$ & 0.469 & 395 \\
\hline Equal access to employment & 0.068 & $\begin{array}{c}0.087^{* * * *} \\
(0.040)\end{array}$ & 0.439 & 923 \\
\hline Mention of subsidy & 0.071 & $\begin{array}{c}0.004 \\
(0.017)\end{array}$ & 0.947 & 923 \\
\hline
\end{tabular}

Standard errors in parentheses

*** $\mathrm{p}<0.01,{ }^{* *} \mathrm{p}<0.05, * \mathrm{p}<0.1$; where $\mathrm{p}$-values are for a one-sided test of proportion testing the null hypothesis that the callback rates for applications with (or sent to a

firm with) and without (or sent to a firm without) the characteristic are equal.

Table 3: Effects of characteristics on callback rates of applications with disability 


\begin{tabular}{|c|c|c|c|c|c|c|c|c|}
\hline & \multirow{2}{*}{$\begin{array}{l}\text { Secretary } \\
\text { (a) }\end{array}$} & \multirow{2}{*}{$\begin{array}{c}\text { Receptionist } \\
\text { (b) }\end{array}$} & \multirow{2}{*}{$\begin{array}{l}\text { Acc. Clerk } \\
\text { (c) }\end{array}$} & \multirow{2}{*}{$\begin{array}{l}\text { Programmer } \\
\text { (d) }\end{array}$} & \multirow{2}{*}{$\begin{array}{l}\text { Total } \\
\text { (e) }\end{array}$} & \multirow{2}{*}{$\begin{array}{c}\text { Total-Access } \\
\text { (f) }\end{array}$} & \multicolumn{2}{|c|}{ Total-interactions } \\
\hline & & & & & & & $\begin{array}{l}\text { Main var. } \\
\quad(\mathrm{g})\end{array}$ & $\begin{array}{l}\text { Inter. } \\
(\mathrm{h})\end{array}$ \\
\hline Disability & $\begin{array}{l}-0.096^{* *} \\
(0.039)\end{array}$ & $\begin{array}{l}-0.105^{* * *} \\
(0.040)\end{array}$ & $\begin{array}{l}-0.117^{* * *} \\
(0.041)\end{array}$ & $\begin{array}{l}0.010 \\
(0.051)\end{array}$ & $\begin{array}{l}-0.080^{* * *} \\
(0.022)\end{array}$ & $\begin{array}{l}-0.105^{*} \\
(0.060)\end{array}$ & $\begin{array}{l}-0.109^{* *} \\
(0.053)\end{array}$ & - \\
\hline Access for wheelchair & - & - & - & - & - & $\begin{array}{l}0.026 \\
(0.060)\end{array}$ & - & - \\
\hline Acc. for wheel. $\times$ disab & - & - & - & - & - & $\begin{array}{c}0.032 \\
(0.065)\end{array}$ & - & - \\
\hline Subsidy $\times$ disab & $\begin{array}{c}0.011 \\
(0.033)\end{array}$ & $\begin{array}{l}-0.018 \\
(0.032)\end{array}$ & $\begin{array}{l}-0.015 \\
(0.022)\end{array}$ & $\begin{array}{c}0.027 \\
(0.042)\end{array}$ & $\begin{array}{c}0.002 \\
(0.017)\end{array}$ & $\begin{array}{c}0.015 \\
(0.028)\end{array}$ & - & $\begin{array}{c}0.000 \\
(0.017)\end{array}$ \\
\hline Yrs since acc. $\times$ disab. & $\begin{array}{l}-0.001 \\
(0.002)\end{array}$ & $\begin{array}{c}0.002 \\
(0.002)\end{array}$ & $\begin{array}{c}0.003 \\
(0.002)\end{array}$ & $\begin{array}{l}-0.002 \\
(0.002)\end{array}$ & $\begin{array}{c}0.000 \\
(0.001)\end{array}$ & $\begin{array}{l}-0.000 \\
(0.002)\end{array}$ & - & $\begin{array}{c}0.000 \\
(0.001)\end{array}$ \\
\hline Male & - & - & $\begin{array}{l}-0.013 \\
(0.029)\end{array}$ & $\begin{array}{c}0.059^{*} \\
(0.035)\end{array}$ & $\begin{array}{l}0.026 \\
(0.023)\end{array}$ & $\begin{array}{c}0.021 \\
(0.049)\end{array}$ & $\begin{array}{l}-0.028 \\
(0.045)\end{array}$ & $\begin{array}{c}0.084 \\
(0.052)\end{array}$ \\
\hline Age - 22 & $\begin{array}{l}0.022^{* *} \\
(0.010)\end{array}$ & $\begin{array}{l}-0.004 \\
(0.008)\end{array}$ & $\begin{array}{l}-0.003 \\
(0.008)\end{array}$ & $\begin{array}{l}-0.013^{*} \\
(0.008)\end{array}$ & $\begin{array}{l}-0.002 \\
(0.004)\end{array}$ & $\begin{array}{l}-0.006 \\
(0.007)\end{array}$ & $\begin{array}{c}0.002 \\
(0.008)\end{array}$ & $\begin{array}{l}-0.007 \\
(0.010)\end{array}$ \\
\hline Experience & $\begin{array}{l}-0.020^{*} \\
(0.010)\end{array}$ & $\begin{array}{c}0.004 \\
(0.008)\end{array}$ & $\begin{array}{l}0.001 \\
(0.008)\end{array}$ & $\begin{array}{c}0.010 \\
(0.008)\end{array}$ & $\begin{array}{c}0.001 \\
(0.004)\end{array}$ & $\begin{array}{c}0.006 \\
(0.008)\end{array}$ & $\begin{array}{l}-0.003 \\
(0.008)\end{array}$ & $\begin{array}{c}0.007 \\
(0.010)\end{array}$ \\
\hline Quebec City & $\begin{array}{l}0.126^{* * *} \\
(0.039)\end{array}$ & $\begin{array}{l}0.117^{* * *} \\
(0.039)\end{array}$ & $\begin{array}{c}0.005 \\
(0.031)\end{array}$ & $\begin{array}{c}0.058 \\
(0.048)\end{array}$ & $\begin{array}{l}0.082^{* * *} \\
(0.020)\end{array}$ & $\begin{array}{l}0.131^{* * *} \\
(0.034)\end{array}$ & $\begin{array}{l}0.068^{*} \\
(0.035)\end{array}$ & $\begin{array}{c}0.021 \\
(0.042)\end{array}$ \\
\hline Not currently working & $\begin{array}{c}0.073 \\
(0.069)\end{array}$ & $\begin{array}{c}0.023 \\
(0.066)\end{array}$ & $\begin{array}{c}0.044 \\
(0.073)\end{array}$ & $\begin{array}{l}-0.025 \\
(0.065)\end{array}$ & $\begin{array}{c}0.022 \\
(0.034)\end{array}$ & $\begin{array}{c}0.039 \\
(0.061)\end{array}$ & $\begin{array}{c}0.023 \\
(0.062)\end{array}$ & $\begin{array}{l}-0.008 \\
(0.073)\end{array}$ \\
\hline $\mathrm{Nb}$ of yrs since last job & $\begin{array}{l}-0.052^{* * *} \\
(0.019)\end{array}$ & $\begin{array}{c}0.005 \\
(0.015)\end{array}$ & $\begin{array}{l}-0.012 \\
(0.017)\end{array}$ & $\begin{array}{l}-0.002 \\
(0.014)\end{array}$ & $\begin{array}{l}-0.010 \\
(0.008)\end{array}$ & $\begin{array}{l}-0.011 \\
(0.015)\end{array}$ & $\begin{array}{l}-0.014 \\
(0.015)\end{array}$ & $\begin{array}{c}0.009 \\
(0.018)\end{array}$ \\
\hline 11 to 25 employees & $\begin{array}{c}0.124^{* *} \\
(0.056)\end{array}$ & $\begin{array}{c}0.027 \\
(0.045)\end{array}$ & $\begin{array}{c}0.007 \\
(0.040)\end{array}$ & $\begin{array}{l}-0.045 \\
(0.053)\end{array}$ & $\begin{array}{c}0.022 \\
(0.024)\end{array}$ & $\begin{array}{l}0.030 \\
(0.040)\end{array}$ & $\begin{array}{c}0.063 \\
(0.051)\end{array}$ & $\begin{array}{l}-0.062 \\
(0.057)\end{array}$ \\
\hline 21 to 50 employees & $\begin{array}{c}0.052 \\
(0.054)\end{array}$ & $\begin{array}{l}-0.028 \\
(0.045)\end{array}$ & $\begin{array}{c}0.073 \\
(0.046)\end{array}$ & $\begin{array}{l}-0.039 \\
(0.062)\end{array}$ & $\begin{array}{c}0.008 \\
(0.025)\end{array}$ & $\begin{array}{c}0.014 \\
(0.042)\end{array}$ & $\begin{array}{c}0.052 \\
(0.051)\end{array}$ & $\begin{array}{l}-0.070 \\
(0.057)\end{array}$ \\
\hline More than 50 empls. & $\begin{array}{c}0.009 \\
(0.037)\end{array}$ & $\begin{array}{l}-0.014 \\
(0.036)\end{array}$ & $\begin{array}{c}0.030 \\
(0.031)\end{array}$ & $\begin{array}{l}-0.050 \\
(0.038)\end{array}$ & $\begin{array}{l}-0.010 \\
(0.018)\end{array}$ & $\begin{array}{c}0.021 \\
(0.033)\end{array}$ & $\begin{array}{l}-0.021 \\
(0.035)\end{array}$ & $\begin{array}{c}0.014 \\
(0.041)\end{array}$ \\
\hline Equal access to empl. & $\begin{array}{l}-0.026 \\
(0.080)\end{array}$ & $\begin{array}{c}0.144 \\
(0.108)\end{array}$ & $\begin{array}{c}0.017 \\
(0.061)\end{array}$ & $\begin{array}{c}0.084 \\
(0.078)\end{array}$ & $\begin{array}{c}0.048 \\
(0.040)\end{array}$ & $\begin{array}{c}0.082 \\
(0.079)\end{array}$ & $\begin{array}{c}0.002 \\
(0.054)\end{array}$ & $\begin{array}{c}0.097 \\
(0.079)\end{array}$ \\
\hline Receptionist & - & - & - & - & $\begin{array}{l}-0.032 \\
(0.024)\end{array}$ & $\begin{array}{l}-0.088 \\
(0.056)\end{array}$ & $\begin{array}{c}0.029 \\
(0.043)\end{array}$ & $\begin{array}{c}0.016 \\
(0.048)\end{array}$ \\
\hline Accounting clerk & - & - & - & - & $\begin{array}{c}0.050^{*} \\
(0.026)\end{array}$ & $\begin{array}{c}0.004 \\
(0.060)\end{array}$ & $\begin{array}{l}-0.012 \\
(0.050)\end{array}$ & $\begin{array}{l}-0.029 \\
(0.054)\end{array}$ \\
\hline Programmer & - & - & - & - & $\begin{array}{c}0.038^{*} \\
(0.022)\end{array}$ & $\begin{array}{c}0.063^{*} \\
(0.037)\end{array}$ & $\begin{array}{c}0.003 \\
(0.052)\end{array}$ & $\begin{array}{c}0.068 \\
(0.059)\end{array}$ \\
\hline Constant & $\begin{array}{l}0.090^{* *} \\
(0.040)\end{array}$ & $\begin{array}{l}0.128^{* * *} \\
(0.046)\end{array}$ & $\begin{array}{c}0.123^{* *} \\
(0.053)\end{array}$ & $\begin{array}{l}0.178^{* * *} \\
(0.061)\end{array}$ & $\begin{array}{l}0.114^{* * *} \\
(0.026)\end{array}$ & $\begin{array}{c}0.039 \\
(0.068)\end{array}$ & $\begin{array}{l}0.133^{* * *} \\
(0.046)\end{array}$ & - \\
\hline Observations & 312 & 451 & 312 & 361 & 1436 & 600 & & \\
\hline
\end{tabular}

(Heteroscedasticity robust standard errors between parentheses)

${ }^{* * *} \mathrm{p}<0.01,{ }^{* *} \mathrm{p}<0.05,{ }^{*} \mathrm{p}<0.1$ (two-sided tests)

Table 4: Linear probability model of the determinants of callback rates for an interview 


\begin{tabular}{|c|c|c|c|c|c|c|c|c|}
\hline & \multirow{2}{*}{$\begin{array}{l}\text { Secretary } \\
\text { (a) }\end{array}$} & \multirow{2}{*}{$\begin{array}{c}\text { Receptionist } \\
\text { (b) }\end{array}$} & \multirow{2}{*}{$\begin{array}{l}\text { Acc. Clerk } \\
\text { (c) }\end{array}$} & \multirow{2}{*}{$\begin{array}{l}\text { Programmer } \\
\text { (d) }\end{array}$} & \multirow{2}{*}{$\begin{array}{c}\text { Total } \\
\text { (e) }\end{array}$} & \multirow{2}{*}{$\begin{array}{c}\text { Total-Access } \\
\text { (f) }\end{array}$} & \multicolumn{2}{|c|}{ Total-interactions } \\
\hline & & & & & & & $\begin{array}{l}\text { Main var. } \\
(\mathrm{g})\end{array}$ & $\begin{array}{l}\text { Inter. } \\
(\mathrm{h})\end{array}$ \\
\hline Disability & $\begin{array}{l}-0.193^{* * *} \\
(0.058)\end{array}$ & $\begin{array}{l}-0.202^{* * *} \\
(0.055)\end{array}$ & $\begin{array}{l}-0.249^{* * *} \\
(0.052)\end{array}$ & $\begin{array}{c}0.026 \\
(0.065)\end{array}$ & $\begin{array}{l}-0.164^{* * *} \\
(0.029)\end{array}$ & $\begin{array}{l}-0.193^{* *} \\
(0.077)\end{array}$ & $\begin{array}{l}-0.169^{* *} \\
(0.068)\end{array}$ & - \\
\hline Access for wheelchair & - & - & - & - & - & $\begin{array}{c}0.002 \\
(0.073)\end{array}$ & - & - \\
\hline Acc. for wheel. $\times$ disab & - & - & - & - & - & $\begin{array}{c}0.021 \\
(0.083)\end{array}$ & - & - \\
\hline Subsidy $\times$ disab & $\begin{array}{l}-0.056 \\
(0.042)\end{array}$ & $\begin{array}{c}0.032 \\
(0.045)\end{array}$ & $\begin{array}{c}0.029 \\
(0.037)\end{array}$ & $\begin{array}{c}0.035 \\
(0.051)\end{array}$ & $\begin{array}{c}0.020 \\
(0.023)\end{array}$ & $\begin{array}{c}0.057 \\
(0.037)\end{array}$ & - & $\begin{array}{c}0.015 \\
(0.023)\end{array}$ \\
\hline Yrs since acc, $\times$ disab. & $\begin{array}{l}-0.003 \\
(0.002)\end{array}$ & $\begin{array}{c}0.001 \\
(0.003)\end{array}$ & $\begin{array}{c}0.004 \\
(0.003)\end{array}$ & $\begin{array}{l}-0.006^{* *} \\
(0.003)\end{array}$ & $\begin{array}{l}-0.001 \\
(0.001)\end{array}$ & $\begin{array}{l}-0.002 \\
(0.002)\end{array}$ & - & $\begin{array}{l}-0.002 \\
(0.001)\end{array}$ \\
\hline Male & - & - & $\begin{array}{c}0.001 \\
(0.041)\end{array}$ & $\begin{array}{l}-0.002 \\
(0.044)\end{array}$ & $\begin{array}{l}-0.001 \\
(0.030)\end{array}$ & $\begin{array}{l}-0.014 \\
(0.065)\end{array}$ & $\begin{array}{l}-0.058 \\
(0.060)\end{array}$ & $\begin{array}{c}0.090 \\
(0.068)\end{array}$ \\
\hline Age -22 & $\begin{array}{c}0.018 \\
(0.012)\end{array}$ & $\begin{array}{l}-0.017 \\
(0.010)\end{array}$ & $\begin{array}{l}-0.010 \\
(0.011)\end{array}$ & $\begin{array}{l}-0.019 * * \\
(0.009)\end{array}$ & $\begin{array}{l}-0.009 \\
(0.005)\end{array}$ & $\begin{array}{l}-0.007 \\
(0.009)\end{array}$ & $\begin{array}{l}-0.004 \\
(0.011)\end{array}$ & $\begin{array}{l}-0.009 \\
(0.012)\end{array}$ \\
\hline Experience & $\begin{array}{l}-0.014 \\
(0.012)\end{array}$ & $\begin{array}{c}0.016 \\
(0.011)\end{array}$ & $\begin{array}{c}0.008 \\
(0.012)\end{array}$ & $\begin{array}{l}0.019^{* *} \\
(0.009)\end{array}$ & $\begin{array}{c}0.009 \\
(0.005)\end{array}$ & $\begin{array}{c}0.009 \\
(0.009)\end{array}$ & $\begin{array}{c}0.004 \\
(0.011)\end{array}$ & $\begin{array}{c}0.009 \\
(0.012)\end{array}$ \\
\hline Quebec City & $\begin{array}{l}0.129^{* * *} \\
(0.048)\end{array}$ & $\begin{array}{l}0.097^{* *} \\
(0.046)\end{array}$ & $\begin{array}{l}-0.018 \\
(0.043)\end{array}$ & $\begin{array}{c}0.105^{*} \\
(0.061)\end{array}$ & $\begin{array}{l}0.081^{* * *} \\
(0.025)\end{array}$ & $\begin{array}{l}0.144^{* * * *} \\
(0.041)\end{array}$ & $\begin{array}{c}0.083^{*} \\
(0.044)\end{array}$ & $\begin{array}{l}-0.008 \\
(0.053)\end{array}$ \\
\hline Not currently working & $\begin{array}{c}0.156^{*} \\
(0.088)\end{array}$ & $\begin{array}{c}0.044 \\
(0.082)\end{array}$ & $\begin{array}{l}-0.006 \\
(0.094)\end{array}$ & $\begin{array}{l}-0.030 \\
(0.090)\end{array}$ & $\begin{array}{c}0.040 \\
(0.044)\end{array}$ & $\begin{array}{c}0.076 \\
(0.073)\end{array}$ & $\begin{array}{c}0.123 \\
(0.079)\end{array}$ & $\begin{array}{l}-0.157^{*} \\
(0.093)\end{array}$ \\
\hline $\mathrm{Nb}$ of yrs since last job & $\begin{array}{l}-0.062^{* * * *} \\
(0.024)\end{array}$ & $\begin{array}{c}0.014 \\
(0.021)\end{array}$ & $\begin{array}{c}0.003 \\
(0.025)\end{array}$ & $\begin{array}{l}-0.011 \\
(0.021)\end{array}$ & $\begin{array}{l}-0.011 \\
(0.012)\end{array}$ & $\begin{array}{l}-0.018 \\
(0.019)\end{array}$ & $\begin{array}{l}-0.030 \\
(0.021)\end{array}$ & $\begin{array}{c}0.038 \\
(0.024)\end{array}$ \\
\hline 11 to 25 employees & $\begin{array}{c}0.168^{* *} \\
(0.069)\end{array}$ & $\begin{array}{c}0.072 \\
(0.058)\end{array}$ & $\begin{array}{c}0.013 \\
(0.059)\end{array}$ & $\begin{array}{c}0.007 \\
(0.070)\end{array}$ & $\begin{array}{c}0.060^{*} \\
(0.032)\end{array}$ & $\begin{array}{c}0.028 \\
(0.049)\end{array}$ & $\begin{array}{c}0.112^{*} \\
(0.062)\end{array}$ & $\begin{array}{l}-0.078 \\
(0.071)\end{array}$ \\
\hline 21 to 50 employees & $\begin{array}{c}0.057 \\
(0.070)\end{array}$ & $\begin{array}{l}-0.002 \\
(0.059)\end{array}$ & $\begin{array}{c}0.057 \\
(0.056)\end{array}$ & $\begin{array}{c}0.095 \\
(0.082)\end{array}$ & $\begin{array}{c}0.045 \\
(0.033)\end{array}$ & $\begin{array}{c}0.047 \\
(0.052)\end{array}$ & $\begin{array}{c}0.090 \\
(0.063)\end{array}$ & $\begin{array}{l}-0.071 \\
(0.073)\end{array}$ \\
\hline More than 50 empls. & $\begin{array}{c}0.090 \\
(0.055)\end{array}$ & $\begin{array}{c}0.046 \\
(0.049)\end{array}$ & $\begin{array}{c}0.081 \\
(0.050)\end{array}$ & $\begin{array}{l}-0.046 \\
(0.048)\end{array}$ & $\begin{array}{c}0.036 \\
(0.025)\end{array}$ & $\begin{array}{c}0.063 \\
(0.041)\end{array}$ & $\begin{array}{c}0.066 \\
(0.050)\end{array}$ & $\begin{array}{l}-0.052 \\
(0.057)\end{array}$ \\
\hline Equal access to empl. & $\begin{array}{l}-0.022 \\
(0.105)\end{array}$ & $\begin{array}{c}0.024 \\
(0.112)\end{array}$ & $\begin{array}{c}0.088 \\
(0.085)\end{array}$ & $\begin{array}{c}0.069 \\
(0.092)\end{array}$ & $\begin{array}{c}0.047 \\
(0.048)\end{array}$ & $\begin{array}{c}0.112 \\
(0.092)\end{array}$ & $\begin{array}{c}0.038 \\
(0.073)\end{array}$ & $\begin{array}{c}0.007 \\
(0.094)\end{array}$ \\
\hline Receptionist & - & - & - & - & $\begin{array}{l}-0.036 \\
(0.032)\end{array}$ & $\begin{array}{l}-0.110^{*} \\
(0.064)\end{array}$ & $\begin{array}{c}0.028 \\
(0.055)\end{array}$ & $\begin{array}{c}0.064 \\
(0.062)\end{array}$ \\
\hline Accounting clerk & - & - & - & - & $\begin{array}{l}0.082^{* *} \\
(0.035)\end{array}$ & $\begin{array}{c}0.078 \\
(0.082)\end{array}$ & $\begin{array}{l}-0.034 \\
(0.065)\end{array}$ & $\begin{array}{c}0.006 \\
(0.072)\end{array}$ \\
\hline Programmer & - & - & - & - & $\begin{array}{l}0.063^{* *} \\
(0.029)\end{array}$ & $\begin{array}{l}0.107^{* *} \\
(0.044)\end{array}$ & $\begin{array}{l}-0.018 \\
(0.068)\end{array}$ & $\begin{array}{c}0.159^{* *} \\
(0.078)\end{array}$ \\
\hline Constant & $\begin{array}{l}0.208^{* * *} \\
(0.053) \\
\end{array}$ & $\begin{array}{l}0.279^{* * *} \\
(0.058) \\
\end{array}$ & $\begin{array}{l}0.252^{* * *} \\
(0.072) \\
\end{array}$ & $\begin{array}{l}0.307^{* * *} \\
(0.072) \\
\end{array}$ & $\begin{array}{l}0.243^{* * *} \\
(0.034) \\
\end{array}$ & $\begin{array}{c}0.159^{*} \\
(0.082) \\
\end{array}$ & $\begin{array}{l}0.245^{* * *} \\
(0.058) \\
\end{array}$ & - \\
\hline Observations & 312 & 451 & 312 & 361 & 1436 & 600 & & \\
\hline
\end{tabular}

(Heteroscedasticity robust standard errors between parentheses)

${ }^{* * *} \mathrm{p}<0.01,{ }^{* *} \mathrm{p}<0.05,{ }^{*} \mathrm{p}<0.1$ (two-sided tests)

Table 5: Linear probability model of the determinants of callback rates for an interview or requesting additional information 


\begin{tabular}{|c|c|c|c|}
\hline & $\begin{array}{l}\text { Lower bound } \\
\text { (a) }\end{array}$ & $\begin{array}{l}\text { Lower one-sided } 95 \% \text { CI } \\
\text { (b) }\end{array}$ & $\begin{array}{l}\text { Observations } \\
\text { (c) }\end{array}$ \\
\hline Secretary & $\begin{array}{l}0.729 \\
(0.113)\end{array}$ & 0.543 & 327 \\
\hline Receptionist & $\begin{array}{l}0.559 \\
(0.117)\end{array}$ & 0.367 & 461 \\
\hline Accounting clerk & $\begin{array}{l}0.728 \\
(0.128)\end{array}$ & 0.518 & 319 \\
\hline Programmer & $\begin{array}{c}0.063 \\
(0.283)\end{array}$ & -0.403 & 370 \\
\hline Montreal & $\begin{array}{l}0.571 \\
(0.091)\end{array}$ & 0.420 & 1059 \\
\hline Quebec City & $\begin{array}{l}0.317 \\
(0.156)\end{array}$ & 0.061 & 418 \\
\hline Not accessible for wheelchairs & $\begin{array}{c}0.713 \\
(0.139)\end{array}$ & 0.485 & 180 \\
\hline Accessible for wheelchairs & $\begin{array}{l}0.425 \\
(0.139)\end{array}$ & 0.197 & 431 \\
\hline Equal acc. emp. $=0$ & $\begin{array}{l}0.535 \\
(0.077)\end{array}$ & 0.409 & 1382 \\
\hline Equal acc. emp. $=1$ & $\begin{array}{c}-0.296 \\
(0.677) \\
\end{array}$ & -1.411 & 95 \\
\hline Total & $\begin{array}{l}0.497 \\
(0.079)\end{array}$ & 0.368 & 1477 \\
\hline
\end{tabular}

Standard errors in parentheses (calculated using the delta method)

Table 6: Estimated bounds of proportion of discriminating firms 


\section{References}

Acemoglu, D. And J. D. Angrist (2001): "Consequences of employment protection? The case of the Americans with Disabilities Act," Journal of Political Economy, 109, $915-957$.

Ameri, M., L. Schur, M. Adya, F. S. Bentley, P. McKay, and D. Kruse (2017): "The Disability Employment Puzzle: A Field Experiment on Employer Hiring Behavior," ILR Review. Forthcoming.

BAERT, S. (2016): "Wage subsidies and hiring chances for the disabled: some causal evidence," The European Journal of Health Economics, 17, 71-86.

Bell, D. And A. Heitmueller (2009): "The Disability Discrimination Act in the UK: Helping or hindering employment among the disabled?" Journal of health economics, 28, $465-480$.

Bertrand, M. And S. Mullainathan (2004): "Are Emily and Greg more employable than Lakisha and Jamal? A field experiment on labor market discrimination," The American Economic Review, 94, 991-1013.

Blundell, R. And T. MaCurdy (1999): "Labor supply: A review of alternative approaches," Handbook of labor economics, 3, 1559-1695.

Bowlus, A. J. AND Z. ECKSTEIN (2002): "Discrimination and skill differences in an equilibrium search model," International Economic Review, 43, 1309-1345.

Canadian Humans Right Commission (2012): "Report on Equality Rights of People with Disabilities," Minister of Public Works and Government Services.

(2015): "The Rights of Persons with Disabilities to Equality and Non-Discrimination: Monitoring the Implementation of the UN Convention of the Rights of Persons with Disabilities in Canada," .

FlabBi, L. (2010): "Gender discrimination estimation in a search model with matching and bargaining," International Economic Review, 51, 745-783.

Gouvernement DU QuÉBEC (2013): "Stratégie nationale pour l'intégration et le maintien en emploi des personnes handicappées: Bilan 2008-2013," Ministère de l'emploi et de la solidarité sociale.

Kauer, L. And E. Deuchert (2017): "Hiring subsidies for people with a disability: Helping or hindering?-Evidence from a small scale social field experiment," International Labour Review, 156, 269-285.

LAHEY, J. N. (2008): "Age, women, and hiring: an experimental study," Journal of Human resources, 43, 30-56. 
Oreopoulos, P. (2011): "Why do skilled immigrants struggle in the labor market? A field experiment with thirteen thousand resumes," American Economic Journal: Economic Policy, 3, 148-171.

Patacchini, E., G. Ragusa, And Y. Zenou (2015): "Unexplored dimensions of discrimination in Europe: homosexuality and physical appearance," Journal of Population Economics, 28, 1045-1073.

Ravaud, J.-F., B. Madiot, And I. Ville (1992): "Discrimination towards disabled people seeking employment," Social Science $\&$ Medicine, 35, 951-958.

Roотн, D.-O. (2009): "Obesity, attractiveness, and differential treatment in hiring a field experiment," Journal of human resources, 44, 710-735.

Ruffle, B. J. And Z. Shtudiner (2014): “Are good-looking people more employable?" Management Science, 61, 1760-1776. 